\title{
Hepatitis C Virus-Related Hepatocellular
} Carcinoma

National Cancer Institute

\section{Source}

National Cancer Institute. Hepatitis C Virus-Related Hepatocellular Carcinoma. NCI

Thesaurus. Code C27688.

A hepatocellular carcinoma that develops following hepatitis $C$ virus exposure and injury of the liver parenchyma. 